\title{
EPISTEMOLOGICAL DIALOGUE AS PROPHETIC: A BLACK THEOLOGICAL PERSPECTIVE ON THE LAND ISSUE
}

\author{
Vuyani Vellem \\ University of Pretoria
}

\begin{abstract}
Land is life and land is our mother. The absence of the content of liberation for the dispossessed in theologies that seek to address the question of land is the 'original' sin of the debate about land in South Africa. The history of the church and land dispossession is a bifurcated, dichotomised discourse of annihilation and quarantine of the disposed. With the rudiments of a Contextual Theology of Land and a Black Theology of Land, the prophetic imagination of the church post-1994 must subject any epistemological views that exclude the internal logic of black Africans to a rigorous hermeneutic of suspicion. Black Africans need land to live first and not to be agents of the commodification of land, a spirit that dominates the debate today.
\end{abstract}

Key Words: $\quad$ Bifurcated; 'Common Physical Space;' Commodification; Hermeneutic of Suspicion

\section{Introduction}

We begin our conversation by attempting to present our understanding of the rationale of Black Theology of liberation especially with regard to land. This is followed by a survey of the role the church has played with regard to the land question. This survey delves into what the 'original' purpose was of each of the models and manifestations of the concept 'church' as this inevitably has a bearing on the prophetic mission of the church in South Africa. The relationship between Black Theology of liberation and a particular form of ecclesiology is important, and in conclusion, the debate on the question of land constantly requires to be subjected to a hermeneutic of suspicion.

\section{The Rationale of a Black Theology of Land}

Land is life! The title of Takatso Mofokeng's article, (1997) "Land is our mother: A Black Theology of Land," is equally telling. Indeed land has sacred, spiritual, cultural and religious features in black Africa to say the least. This is how black Africans view their land. Accordingly, land is an integral part of the whole constellation of life, which cannot be separated into dichotomised compartments or spheres in the African ethical view of life. Sadly, since the encounter between white and black in South Africa, the epistemological view of land by Africans was violently dismantled and perhaps even so in the current democratic dispensation. Black African people bury their umbilical cords, foreskins and their dead in the land. They practise their religion on land. Land is the rendezvous of their 
liturgical rhythms of dance and song in their celebration of life. Land is life. ${ }^{1}$ Land has a body. Land has a womb! Land can be scarred!

Our reflection refers to two important conferences on land since the demise of apartheid: The Rustenburg Conference, ${ }^{2}$ and another on Church, Land and Poverty, in 1997, hosted jointly by the South African Council of Churches (SACC) and the National Land Committee (NLC). To set the scene for our conversation Willem Saayman's article is selected from a collection of papers presented at this Conference by the SACC and the NLC, published by David Gillan in 1998. One of the positions assumed in this paper is that the prophetic voice of the church in post-1994 South Africa is either absent or outsmarted by the dominant, hegemonic consciousness of market fundamentalism that has accompanied the first twenty years of democracy. ${ }^{3}$ That Takatso Mofokeng already lamented the absence of a theology of land in the Rustenburg Declaration and rightly posited that "land repossession is a physical, ideological and spiritual struggle," (1997:48) shapes the rationale of this paper. The South African church could possibly be prophetic when she hears the voice of the powerless echoing: 'Come out of the mission station and be prophetic.' By interpreting Prophetic Theology from a black perspective, this paper punctuates a particular understanding of faith that became historicised in our struggle for liberation namely, faith as socio-political praxis. This means that an interpretation of the gospel that is devoid of the content of liberation remains shallow in the historical context of black oppression and dispossession. A commitment to a particular historical project for the liberation of the marginalised and the poor, distinguishes one form of theology from another. The lessons of the past twenty years of democracy in South Africa should alert us to epistemological dialogue as a prophetic moment of our time.

By the turn of the twentieth century, Black Theology of liberation had established the seamless triad of Liberation, Inculturation and Reconciliation for doing theology; ipso facto, conversations and solutions to the land question require a deepened understanding of the festering wounds inflicted by modernity against blacks, the grammar and language that is quintessentially black African for any reconciliation to be achieved - not cheap reconciliation. There is no possible solution for the land question without the symbolic significance of black African values in the construction of land imaginaries post-1994. The comprehensive liberation of black Africans is a sine qua non for any imagined solutions for land in South Africa.

See the draft statement of the Theological Consultation on Economy of Life scheduled for 26-30 October 2014 in India entitled: "The Economy of Life, Justice and Peace for All: A Call to Action." This statement is a product of the AGAPE process within the World Council of Churches and the section on "Theological and Spiritual Affirmations" alludes among others to the point we are making: "We are inspired by Indigenous peoples' image of 'Land is Life' (Macliing Dulag) which recognises that the lives of people and the land are woven together in mutual interdependence," p.1.

2 The Rustenburg Conference produced a declaration which alluded to issues of land. For example on p.2 of the Declaration, under section 2 which deals with Confession, 2.3 states: "We remember with sorrow the victims of apartheid who have suffered and continue to suffer humiliation, dispossession and death." Section 5 of the Declaration deals with a subheading entitled "Restitution and a commitment to action" and under this very section, 5.2. states that the church should examine its land ownership.

3 I have argued elsewhere that the opiate of neoliberal democracy has to be unmasked. See VS Vellem, 2012. "The opiate of neoliberal Globalization and the dawn of Democracy in South Africa" in Theologia Viatorum, Volume 36.1.,76-93. 


\section{The Church and Land in South Africa}

Dirkie Smit (2007) ${ }^{4}$ has articulated a number of ways in which the concept 'church' could be understood.

Accordingly, the church could be viewed as an individual person, an ecumenical body and its witness, a denomination, or even a congregation in worship to mention but a few possibilities. This articulation of the church in its varied forms and structural manifestations, as Koopman (2005) also used it, has been helpful in explaining what the role of the church could be in public life, particularly in democratic South Africa. Koopman says:

In this article I speak of theology as ecclesial theology; whereby theology, as an academic discipline is [practised] in, with and for the church. In using the term 'church' I follow the helpful distinction of the South African theologian, Dirkie Smit, namely that the church has six manifestations or forms: A worship service, a local congregation, a denomination, ecumenical bodies, individual Christians engaged in their normal daily activities, individual Christians as volunteers in various organs of civil society (2005:1).

This understanding is helpful. Following this interpretation or definition of the manifestation of the church, one might ask whether there is a role an individual Christian has played or could even play in future for the solutions we require for land justice in our land. In the same way the question about all its manifestations - church - could be posed. While we should not essentially have a problem with this definition of the church and indeed its analytical helpfulness in the complex questions related to the role of the church in public life, it may be also necessary to commence our definition of the church elsewhere.

The undeniable bifurcated state ${ }^{5}$ of the church in South Africa is probably the most potent of the starting points of any definition of the church in South Africa. Indeed in a number of works that Mamdani has published, his insistence on the nature of colonial power as a bifurcated state, in other words, a form of power that is 'racialised' and 'tribalised' with social spaces that are dichotomised as either civil or savage - even legal discourses that are civil and customary - it is vital that we look at the church in South Africa within these bifurcated horizons of power in physical, concrete and imaginary terms. Anyone who denies the existence of two churches in South Africa, one essentially white, rich or privileged and another one black, poor and marginalised could be a threat to any genuine ecclesiological dialogue in our land.

At best in our South African history of the church, there are three models: The Settler, Missionary and African Initiated. The Settler Model of the church entails the formation of congregations by settler communities in South Africa that ultimately became independent denominations in our history. What distinguishes this model from the others and vice versa is the 'original' purpose for its existence. Settler communities in South Africa cannot be viewed without the establishment of the refreshment station in Cape Town by Jan Van Riebeeck for purposes of trade. The formation of settler churches is thus a consequence an aftermath - of the trade interest that was the fundamental reason for the establishment of a refreshment station in Cape Town. Missions followed this 'original' purpose. One great example of the relationship between the missionary enterprise and the 'original' purpose of trade is the 'Gospel of Work' which used theology to justify cheap labour and thus the

\footnotetext{
4 The Afrikaans version of this article was published in 1996 as "Oor die unieke openbare rol van die kerk" in Tydskrif vir die Geesteswetensakappe, September:190-204.

5 My use of the term 'bifurcated state' derives from Mahmood Mamdani's 1996 work, Citizen and Subject: Contemporary Africa and the Legacy of Late Colonialism, Princeton Studies in Culture/Power/History. Kampala: Fountain, in which he analyses the nature of colonial power and its resultant power structure.
} 
denigration of black dignity. African Initiated Churches are by and large a response to these two models: Settler and Missionary, notwithstanding their ambiguity, deficiencies and contradictions. John de Gruchy (2014) acknowledges these models even though he adds others, probably due to the topic he discusses, namely, the quest for identity among the socalled main line churches in South Africa.

What has become the manifestation of the church in South Africa today a la Smit, will have its roots and origins in these three models of the church. For this reason, the distinct 'original' purposes of and their theological enclaves have a bearing on how one looks at the prophetic dimension of the church in South Africa today. The ecclesiological approach of this paper, from which the argument for a prophetic contribution of the church is based, could be captured by the words of Takatso Mofokeng when he says:

It is shocking to notice that the white colonial church failed to address this violent process of dispossession as a theological issue. It was never called a sin against God and against African people. This church also failed to develop a theology that could have stopped this process, in spite of the fact that violence was perpetrated right in front of their eyes. The missionaries saw our people turned into beggars and wanderers and instead of confronting those who sinned against them, they identified the victims as objects of mission who were taught not to steal and not to be violent. They were taught that their inheritance was safe in heaven from thieves (1997:44).

The colonial church alluded to in these sentiments above is viewed as a representation of the Settler Model, while the missionary role described above is self-explanatory, indeed as a representative of the 'original' purpose of the Missionary Model of the church in South Africa. Willem Saayman (1998:153) says:

One only needs to remind oneself about the often told story: "When the missionaries came, we African people had the land and they had the Bible. They said, 'Let us pray', and when we opened our eyes after the prayer, they had the land and we had the Bible."

Saayman explains this statement by saying it is a 'perception.' It is doubtful that any Black Theology of liberation would treat that statement as a perception. ${ }^{6}$ Nonetheless, Saayman argues, even though he does not investigate any truth in this statement that it is important to assert the centrality of the land question in this history of the church and missions in South Africa. Saayman examines among other things, the different ways in which land ownership became part of the problem in South African history. He seems to suggest that this clash on the concept of landownership has to be understood as the cause for "breakdown in communication" between blacks and whites. Saayman explains that Christians in South Africa need to understand that land cannot be understood or perceived merely as a commodity. He further suggests that the problem of land requires an intercultural interpretation in the light of the brokenness of our history and concludes his argument by making missiological propositions for a "contextual theology of land." So far, by proposing a contextual theology of land, Saayman affirms what Mofokeng decries above: The absence of a theology of land 'originally' from the Settler and Missionary Models of theology, ipso facto, their ecclesiology.

Some of the aspects that Sayman deems important for a theology of land are worth mentioning in passing. He says that we could do better if we understood land as God's property against the legal and economic interpretations that were used in this history of the

6 See the interpretation of this statement by Takatso Mofokeng, 1992, "The Crucified and Permanent Crossbearing," in Journal of Black Theology, Vol.7. No.1:20-30. 
church and mission in South Africa that seemed to have seen this matter otherwise - perhaps perceiving ownership of land as by the gods of gold and the market, if one remembers the economics of extraction that went along with the conquest of the black African people. Mofokeng equally discusses aspects of refusal of dispossession by black Africans, the agency of the dispossessed, types of land in contest and repossession as potent themes for a Black Theology of Land. Boesak (2009:21-47) also uses the notion of "a Theology of refusal" to capture the entire spirit of a Black Theology of liberation that developed mostly within the African Initiated model of the church in South Africa. ${ }^{7}$ Indeed our ecclesiology should begin with this statement: "They said, 'Let us pray', and when we opened our eyes after the prayer, they had the land and we had the Bible."

This is a statement of refusal, a call for an intercultural approach to the land question and an assertion of black African agency in the quest for land redistribution in South Africa. The ecclesiological challenge of land dispossession, particularly the absence of the prophetic moment in the Settler and Missionary Models of the church, could be deeply probed when we hear from yet another voice, Lamin Sanneh. Sanneh begins by tracing the history of race and ethnicity to argue for the transformation of Christianity (2001). One of the points he makes which is vital for our conversation when considering the American example is that America, having been involved in three hundred years of ethnic conflict with native Americans found itself faced with two options: "Extinction of the Native races or permanent quarantine in native reserves" (2001:4). This background, namely the choice between the extinction of the native and permanent quarantine of the native in native reserves, is important to help us grasp the meaning of the categories such as 'race', 'tribe' and so forth in understanding the history of the West. Lanneh says, "Race or tribe is not a self-applied designation: It is imposed in all its dense meaning. It entails the cultural meaning of a people with no historical record, specimens of nature unrefined by discipline, struggle, and self-control" (2001:5). Racism thus signifies a people without history or even knowledge of history. This is what the missionary enterprise in its racial theory and thus its attendant ecclesiological structures and models implanted in Africa. Sadly this mind-set still exists even to this day. Sanneh continues to argue by citing a few American intellectuals that became outstanding in their imaginary of race theory such as Trevor-Roper who contended that "the history of the world, for the last five centuries, in so far as it has significance, has been European history".

So in Western history, blacks were given an objective status in anthropology by classifications such as 'race' and 'tribe.' One might ask, what is the real point of repeating this repugnant past in a South Africa that is now 'liberated' from this bigotry? Let me cite Lanneh to respond to this question:

Africans are not like children, fixed for life from the first white impressions. Thus you do not have to deny the presence of Europeans in Africa to believe that history abides by its own internal logic, that African agency is authentic, that African themes are original, and that an African outlook on life shapes people's historical and moral consciousness (2001:11).

It stands to reason then that the encounter between Europe and Africa cannot be simplified to such an extent that black Africans are portrayed as being unable to turn to

See also the articles by Modise, L \& Mtshiselwa, N 2013. "The Natives Land Act of 1913 engineered the poverty of Black South Africans," in Studia Historiae Ecclesiasticae XXXIX 2: 359-378 and Lephakga, T 2013. "The history of theologised politics of South Africa, the 1913 Land Act and its impact on the flight from the black self," in Studia Historiae Ecclesiasticae XXXIX 2:379-400. 
their own account the things that the West introduced to them. The internal logic of black African knowledge, black African agency, black African originality and black African historical and moral consciousness are central to the land question in South Africa. Moreover, as Sanneh reminds us, we need to understand that race and ethnicity are constructs used, particularly in South Africa, to answer the question of the "common physical space" that whites and black Africans happen to share in South Africa. To emphasise this point, we need to remember that apartheid is the supreme example of racism within the provenance of Europe and the West. This does not make South Africa any different from other parts of the continent. The point is this: "As long as Europe was physically separate from Africa there would have been no need to introduce" racial policies of inequality (Sanneh 2011:13-14). The South African case should be understood as 'Europe now having to physically inhabit and dwell on African land' - indeed to share the same space with black Africans on this continent and in our land. For this reason racial theory was designed "to capture and distribute dislocated Africans, to entrap unsuspecting hinterland populations, and to punish the recalcitrant among mission-educated natives for being inclined to step outside their place in the scheme of things" (Sanneh 2011:14).

This is where the poignancy of Mamdani's analysis lies. This is where the thrust of Black Consciousness and a Black Theology of liberation lies - in their refusal against the capturing, distribution, entrapment and punishment of black Africans in their total existence as human beings. Our appeal to Sanneh makes an important contribution to the argument put across in this conversation. Western Missions aligned themselves to this historical fault line. When we talk about the church in South Africa, it is implausible to define the church and its mission without in one way or another giving credence to this history or denouncing it. The problem of the land in South Africa is the problem of dichotomies: Mission-Station, Colonial land-Native Reserve, Amaqaba-Amaghobhoka, and extinction-quarantine - a quintessential state of bifurcation. "The race policy of the colonial empire was the most wholehearted preferential quota program ever undertaken in history, and it was blacks who paid the price for it" (2001:13).

So, when black Africans opened their eyes, the land was gone and they were left only with the Bible in their hands. Black Theology of liberation has taught that there are differences we must make in understanding oppression. Mofokeng (1997) writes that oppressors need the oppressed. This means that domination and hegemony, albeit different from genocide, at least in the $19^{\text {th }}$ century, are maintained through forms of perpetual quarantines of black Africans in their physical, spiritual and psychological spaces for the sole benefit of superior whites and the wealthy. In the $21^{\text {st }}$ century it is no longer quarantined spaces for inferior people, but a combination of genocide and quarantined spaces. $^{8}$ Black Theology of liberation has long ago proposed a theology of land. It is not accidental that there has not been a clearly developed theology of land in the Christian tradition whose 'original' purpose is trade and violated black Africans lives. Even if these models were to develop any theology of land, their credibility would remain in question in as much as any talk about land in South Africa today would be futile without a hermeneutic of suspicion.

8 See works on the Accra Confession and the Confession itself. 


\section{Black Theology of Liberation and Prophetic Imagination}

The 'zinc forest' that has become a common spectacle in all our major South Africa cities $m e k h u k h u$ - in cities where employment looks promising for the masses of the poor people of this country is of itself and is itself a prophetic expression against something qualitatively wrong with our South African democratic era. ${ }^{9}$ The signification that this spectacle of mekhukhu eloquently aggregates is that the South African morass of poverty, unemployment and inequality (PUI) as Terreblanche (2012) coins them, falls right squarely into land dispossession. ${ }^{10}$ The relationship between Prophetic Theology and Black Theology of liberation in South Africa is first about the absence of a prophetic instance a la Boesak in the missionary theological imagination, due to its collusion with colonialism and the conquest of the black people of this land. This is what Mofokeng has also argued.

One of the best expressions of a living death in the squatter camps - to expand somewhat on this notion by Fanon - is how dead bodies become alive for profit. At Thabo Mbeki Village, land eviction is tantamount to parting ways with the family graves, the places where others have their umbilical cords buried and thus parting with their identity, which is impossible to imagine without land. There is an interesting contrast here between the pre-1994 era and the post-1994 era in South Africa without exaggeration, given the constant threat of HIV and Aids to life in these places. If the migratory labour system extracted living blood from an average black African person, for the post-1994 neoliberal democracy and economics, literally, dead bodies provide currency for profit; they are living blood for a death-dealing civilisation that has found its zenith in the convergence of politics, the current dominant model of economics and military violence. According to Anton Harber, a legal process of declaring such places as Diepsloot and its neighbouring Thabo Mbeki Village into recognised residences in the city takes about fifteen years, at least in the case of Diepsloot. At Thabo Mbeki Village, this evicted community participated in the elections in 2004, 2009 and the respective Provincial elections that have been held inbetween. Now they have also participated in the 2014 elections. They are still not declared, in other words, recognised legally by Johannesburg City. What an irony!

A landless community can be used as voting fodder, but they will wait for fifteen years or more before they are recognised legally, obviously with all the implications of the socalled 'service delivery.' There are children who are born at Thabo Mbeki Village. A child who was born there in 2004 is already ten years old. Thabo Mbeki Village has not yet been declared. That child does not know tap water, electricity, a decent house that another one, a stone's throw away, is enjoying as a birth right. If Peter Berger's thesis of knowledge as a social construction is anything to go by, then there is a difference in the knowledge that a child who grows in such circumstances and another in a suburb is forming. Some years ago, Cone described Black Theology of liberation as a "theology of the ghetto." The relationship

$9 \quad$ See Vellem, VS 2010. "Prophetic witness in Black Theology - with special reference to the Kairos Document" in HTS Teologiese Studies /Theological Studies Journal 66(1), Art. \#800, 6 pages.

DOI:10.4102/hts.v66i1.800 and Vellem, V 2014. "Life-giving Assets at a Johannesburg Informal Settlement: Black Faith and the False Gods of Multiculturalism in the Twenty-First Century, in Smith, D, Ackah, W \& Reddie, A G (eds.) Churches, Blackness, and Contested Multiculturalism. New York: Palgrave MacMillan. and Lephakga (2013). Modise \& Mthiselwa see the Land Act and thus land dispossession as the root cause of poverty as their discussion is around poverty alleviation in South Africa. Lephakga sees the Land Act of 1913, and thus land dispossession, as the cause of psychological, economic and structural ills. Most importantly, he argues that landlessness creates serious identity problems and in my own words, of the landless becoming mental, physical, political and economic hostages of a parasitic discourse of oppression. 
between Prophetic Theology and Black Theology of liberation is thus a relationship of confessional faith in the praxis of historical circumstances of ghetto life, living death, not merely pointing to an alluring alternative vision as most of the versions of Prophetic Theology seem to be geared for in post-1994 South Africa.

The creation of the landless urban labourer - the cheap migrant labourer dislodged from home - places security, land and labour as inseparable components of the narrative of landhunger unfolding in the historical promulgation of Acts such as the opprobrious 1913 Land Act and Pass Laws which tied cheap labour to particular employers throughout the colonial and apartheid administrations in South Africa and the struggle for liberation. The discovery of gold and diamonds directly created a mass of landless urban labourers followed by a heightened brutality of forced removals since 1948 up to the 1990s before the demise of apartheid. By the time of the transition to democracy, South Africa had become a land bifurcated between the beneficiaries of 'blood land' and the wounded, humiliated victims of land dispossession.

The dominant paradigm in democratic South Africa as shown by the White Paper, first in the period of transition, the Rustenburg Declaration and the current constitutional dispensation is arguably that of the commodification of land. Stories of eviction, property devaluation and the mushrooming of informal settlements have continued into the new democratic South Africa. Theological reflection on land in South Africa should begin inter alia from the black African understanding of land as a sacred gift from God, as Mofokeng and others have argued.

Black Africans understand land to be a God-given resource for life, not only as a source or tool of life, but verily as an intrinsic part of life itself. Black Africans believe that land has moral and spiritual significance central to their view of life that values the integrity and harmony of creation. Land for black Africans is nahalah, it is inheritance that renders its reification and commodification by the market a perpetual hoax. Given the history of the Western Christian tradition and its use of the Bible in the dispossession and oppression of black Africans, land in South Africa post-1994 is a hermeneutically contested question. The beneficiaries of land dispossession and victims alike are Christians inspired by the same Bible. Hermeneutical starting points therefore, can legitimise powerful traditions of the landed against the landless weaker traditions that are silenced both in the Bible and our current local and global political discourses. Land is life. Land is justice. Let us conclude our conversation on the note of a hermeneutic of suspicion.

\section{A Hermeneutic of Suspicion}

There is obviously a different perspective from the one that we have outlined so far. Understandably, there are epistemological differences in our theological views and certainly our approach to the question of land. Karen Lebacqz offers some of the views which are opposed to the liberation paradigm. Often, she explains, this paradigm of theology fails to provide empirical facts to substantiate its interpretation of the situation. The view of the liberation paradigm on sin is narrow; as the argument goes, it equates sin with oppressive structures. Moreover, liberation is utopian while it also uses Scripture selectively. The notion of praxis is also critiqued as some feel that it squeezes out faith and collapses God's activity in the quest for historical justice.

Most recently, though not a theologian, RW Johnson has expressed similar views. Against what Johnson designates as the African Nationalist version of history, he proposes that there is a need to get the history 'right' in building South Africa post-1994. He argues 
that African Nationalism must come to grips with the fact that we are dealing here with white rule that lasted less than fifty years. Moreover, without denying the atrocities and injustices caused by colonialism and apartheid, he nonetheless argues that South Africans must accept that colonial and apartheid rule had great achievements. There is a need to understand that there were emancipatory possibilities in mission schools, colleges and universities built by the colonial administrations.

During apartheid, there were many schools and hospitals that were built for blacks. The point here is that Johnson attacks the foundations of what he dubs African Nationalist history by arguing that it is imaginary history. By implication, Black Theology of liberation or Prophetic Theology is based on imaginary history. About land Johnson says:

Similarly, one often hears that whites still own 80 per cent of land, though it is easy to see that once you add up the old bantustans and the vast tracts of government land, let alone the urban areas and the game reserves, this cannot possibly be true. Nor indeed could it have been true for quite some time (2010:574).

By challenging what he argues are the empirical distortions in the African Nationalist history of the struggle, he concludes that "One cannot build a sense of shared national community by trying to inculcate a burning sense of grievance and entitlement in a majority and a corresponding sense of fear and guilt among the rest" (2010:582). The primary reason for the inclusion of these views is to illustrate epistemological differences between Black Prophetic views and other views held mostly by whites and not necessarily by most whites. Second, one needs to subject these views to a hermeneutic of suspicion as they continue to be expressed not as overtly and explicitly as stated by Johnson, who was a member of the ANC.

Our brief response is that we should not for once be fazed by the use of the language espoused to attack the liberation paradigm but the foundations of the argument. We do not even have to think about the emancipatory possibilities inherent in the history of colonialism and apartheid for us to build a new South Africa. With regard to land, no one can refute the fact that the skills acquired by those who benefited from colonialism and apartheid are indispensable for land redistribution in South Africa. Black Theology of liberation is not wholly oblivious to these realities and in this article; we have demonstrated this point through Sanneh's arguments above. Essentially, Black Theology of liberation does not perceive its goal as a total rejection of what could be helpful even though resulting from the history of oppression. As Sanneh points out, the issue for us lies here: The more black Africans want to be included in the white and Western epistemological frames, the more they are excluded. Tiyo Soga's story is one of the best examples of this experience. The more they seek to embrace and appreciate the skills and the good that comes out of the repugnant history of colonialism and apartheid, the more they are reminded that they are black and cannot attain these skills. Black Theology erupts out of this history of the struggle for inclusion.

Cornel West makes a pivotal point in his discussion of the difference between exclusion and liberation. Arising out of the perpetual exclusion of blacks even when they attempt and struggle to be included, West says Black Theology of liberation must see the unmasking of falsehoods and overcome the present mystification of oppression as one of its tasks. Black Theology and thus Prophetic Theology, are not about inclusion, but transformation. 


\section{Conclusion}

The rationale of Black Theology is to refuse to trivialise the fact of dispossession and the cultural death of black African people. Black Africans cannot continue to be quarantined as people who have no skills, without knowledge and even a history of relationships with their motherland. Epistemological dialogue is a prophetic moment of our time.

\section{BIBLIOGRAPHY}

Anton, Harber 2011. Diepsloot. Cape Town, Johannesburg: Jonathan Ball Publishers. Conradie, EM \& Klaasen, J (eds.) 2014. The Quest for Identity in so-called Mainline Churches in South Africa. Stellenbosch: Sun Press.

De Gruchy, J 2005. The Struggle of the Church in South Africa. Minneapolis: Fortress. Gillan, DS 1998 (ed.). Church, Land and Poverty: Community Struggles,Land Reform and the Policy Framework on Church Land. Johannesburg: SACC.

Johnson, RW 2010 South Africa's Brave New World-The Beloved Country since the End of Apartheid. London: Penguin Books.

Koopman, N 2005. "Churches, Democracy and the Public Sphere' http://www.accc-ct.org.za/koopman.html, viewed on 15-08-2014.

Lephakga, T 2013. "The History of Theologised Politics of South Africa, the 1913 Land Act and its Impact on the Flight from the Black Self, in Studia Historiae Ecclesiasticae XXXIX 2:379-400.

Mamdani, M 1996. Citizen and Subject: Contemporary Africa and the Legacy of Late Colonialism. Princeton Studies in Culture/Power/History. Kamapala: Fountain.

Modise, L \& Mtshiselwa, N 2013. "The Natives Land Act of 1913 engineered the Poverty of Black South Africans," in Studia Historiae Ecclesiasticae XXXIX 2:359-378

Mofokeng, T 1997. "Land is our Mother: A Black Theology of Land” in Guma, M (ed.), An African Challenge to the Church in the $21^{\text {st }}$ Century. Cape Town: Salty Print. 42-56.

Mofokeng, T 1992 "The Crucified and Permanent Cross-bearing." in Journal of Black Theology, Vol.7. No.1:20-30.

Mosala, I 1997. “Ownership or Non-Ownership of Land” in Guma, M (ed.), An African Challenge to the Church in the $21^{\text {st }}$ Century. Cape Town: Salty Print. 57-54.

Sanneh, L 2001 "The African Transformation of Christianity: Comparative Reflections on Ethnicity and Religious Mobilization in Africa" in Hopkins, D, Lorentzen, LA, Mendieta, E \& Batstone, D (electronic book). Religions/Globalizations: Theories and Cases. London: London Press. 1-79.

Smit, D 2007. "On the impact of the Church in South Africa after the Collapse of the Apartheid Regime" in Conradie, E (ed.) Essays in Public Theology: Stellenbosch: Sun Media. 57-74.

Smit, D 1996 "Oor die unieke openbare rol van die kerk" in Tydskrif vir Geesteswetensakappe, September:190-204

Terreblanche, S 2012. Lost in Transformation: South Africa's Search for a New Future. Sandton: KMM. 
http://scriptura.journals.ac.za

Epistemological Dialogue as Prophetic: A Black Theological Perspective on the Land Issue

Vellem, V 2014. "Life-giving Assets at a Johannesburg Informal Settlement: Black Faith and the False Gods of Multiculturalism in the 21st Century," in Smith, D, Ackah, W \& Reddie, AG (eds.). Churches, Blackness, and Contested Multiculturalism. New York: Palgrave MacMillan. 207-216.

Vellem, V 2010. "Prophetic Witness in Black Theology - with special Reference to the Kairos Document," in HTS Teologiese Studies / Theological Studies Journal 66(1), Art. \#800, 6 pages. DOI:10.4102/hts.v66i1.800.

Vellem, VS 2012. "The opiate of neoliberal Globalization and the dawn of Democracy in South Africa" in Theologia Viatorum, Volume 36.1:76-93. 